\section{(6) OPEN ACCESS}

\title{
Tobacco industry misappropriation of American Indian culture and traditional tobacco
}

\author{
Joanne D'Silva, ${ }^{1,2}$ Erin O'Gara, ${ }^{1}$ Nicole T Villaluz ${ }^{3,4}$
}

\begin{abstract}
- Additional material is published online only. To view please visit the journal online (http://dx.doi.org/10.1136/ tobaccocontrol-2017-053950).

${ }^{1}$ Research Department, ClearWay Minnesota, Minneapolis, Minnesota, USA ${ }^{2}$ Department of Behavioral and Community Health, University of Maryland School of Public Health, College Park, Maryland, USA

${ }^{3}$ Community Development Department, ClearWay Minnesota, Minneapolis, Minnesota, USA

${ }^{4}$ Hidatsa/Assiniboine/Chamorro, USA
\end{abstract}

\section{Correspondence to} Joanne D'Silva, Research Department, Clear Way Minnesota, Minneapolis, MN 55425, USA;

jdsilva@clearwaymn.org

JD'S, EO'G and NTV contributed equally.

Received 14 July 2017

Revised 18 December 2017

Accepted 3 January 2018

Published Online First

19 February 2018

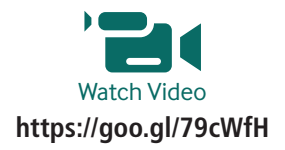

Check for updates

To cite: D'Silva J, O'Gara E, Villaluz NT. Tob Control 2018:27:e57-e64.

\section{ABSTRACT}

Objective Describe the extent to which tobacco industry marketing tactics incorporated American Indian culture and traditional tobacco.

Methods A keyword search of industry documents was conducted using document archives from the Truth Tobacco Documents Library. Tobacco industry documents $(n=76)$ were analysed for themes.

Results Tobacco industry marketing tactics have incorporated American Indian culture and traditional tobacco since at least the 1930s, with these tactics prominently highlighted during the 1990s with Natural American Spirit cigarettes. Documents revealed the use of American Indian imagery such as traditional headdresses and other cultural symbols in product branding and the portrayal of harmful stereotypes of Native people in advertising. The historical and cultural significance of traditional tobacco was used to validate commercially available tobacco.

Conclusions The tobacco industry has misappropriated culture and traditional tobacco by misrepresenting American Indian traditions, values and beliefs to market and sell their products for profit. Findings underscore the need for ongoing monitoring of tobacco industry marketing tactics directed at exploiting Native culture and counter-marketing tactics that raise awareness about the distinction between commercial and traditional tobacco use. Such efforts should be embedded within a culturally sensitive framework to reduce the burden of commercial tobacco use.

\section{INTRODUCTION}

The first national company to draw on the 'mystique of Indianness' was Red Man chewing tobacco in $1904 .^{1}$ Since then, American Indian imagery has appeared on other tobacco products, such as Geronimo cigarettes, with colourful and attractive packaging designed to appeal to ethnic pride. ${ }^{2}$ Recent studies have examined how Natural American Spirit (NAS) cigarettes, which feature Native imagery alongside 'natural' and 'additive-free' text descriptors, may suggest a 'safer' product to consumers. ${ }^{34}$ Unger et $a l^{5}$ suggest that the use of Native imagery is used to portray commercial tobacco as natural and convey a spiritual experience to consumers by blurring the distinction between commercial and traditional tobacco.

Traditional tobacco, used for spiritual, ceremonial and cultural purposes, plays a central role in the life of many, but not all, Native people. It is important to distinguish between commercial and traditional tobacco use in American Indian communities: commercial tobacco causes death and disease, whereas traditional or sacred tobacco use is guided by protocols and teachings that honour the Creator. ${ }^{6}$ This relationship with traditional tobacco dates back to the beginning of time and is embedded within many creation stories. ${ }^{7}$ Traditional tobacco currently and historically has been used to honour and welcome guests, to communicate with the Creator, as a prayer offering or to share wisdom. ${ }^{7}$ Traditional tobacco can be placed on the ground in offerings, burned for cleansing purposes or smoked in a pipe during rituals. ${ }^{8}$

For centuries, strict protocols have guided practices for cultivating and harvesting tobacco plants. ${ }^{9}$ Following colonisation, tobacco seeds were exported to Europe and tobacco use was popularised among non-Native peoples. Cultivation of a commercialised tobacco crop paved the way for the proliferation of manufactured tobacco. ${ }^{10}$ At the same time, the extermination and assimilation policies of the US federal government during the 19th and 20th centuries further marginalised cultural practices for Native people. ${ }^{11} 12$ Using traditional tobacco was forbidden by the US government until 1978 when the American Indian Religious Freedom Act extended protections to "preserve for American Indians their inherent right to freedom to believe, express, and exercise the traditional religions". ${ }^{13}$ Despite these challenges and the high prevalence of commercial tobacco use among American Indians relative to the general population, ${ }^{14}$ traditional tobacco continues to play a central role in the life of many Native people, and efforts to address commercial tobacco's harms should acknowledge the history and value of traditional tobacco. ${ }^{8}$

The tobacco industry's influence in shaping tobacco disparities among racial and ethnic minority populations is well documented. ${ }^{15}$ Marketing strategically targets consumers' values, attitudes and beliefs, ${ }^{16} 17$ and tobacco advertising and promotions are directly linked to increased tobacco initiation and consumption. ${ }^{18}$ Prior research has also documented the use of cultural attributes and ethnic identities to market tobacco products and create brand identity. ${ }^{19}$ For example, tobacco industry documents detail how R.J. Reynolds (RJR) incorporated Spanish language, cultural values and sponsorship of musical and other community festivals as a culturally relevant marketing strategy to target Hispanics. ${ }^{16}$ Co-opting culture, including images, ethnic symbols and traditional objects, has been employed to target population subgroups and to increase the appeal of products to a broad range of consumers. ${ }^{19}$

Despite evidence of the industry's marketing tactics to associate tobacco products with valued cultural attributes ${ }^{20}$ as well as the long history of using Native imagery on packaging, we are unaware 
of any studies to date that have specifically explored the use of Native cultural attributes in industry document archives. This study sought to answer the following research question: To what extent have tobacco industry marketing tactics incorporated American Indian culture and traditional tobacco? Our findings have the potential to fill an existing gap in the literature and inform counter-marketing strategies to reduce commercial tobacco use.

\section{METHODS}

A textual analysis was conducted on documents from the Truth Tobacco Industry Documents Library (https://industrydocuments.library.ucsf.edu/tobacco/) between 1 September 2016 and 1 July 2017. No date or collection restrictions were imposed. We used widely accepted iterative 'snowball' sampling techniques, which have been detailed in previous tobacco industry document research. $^{21} 22$ Searches began with broad terms such as 'American Indian', 'Native American' and 'traditional tobacco'. Subsequent searches included more specific terms around imagery, cultural terms for 'tobacco' and both formal and stereotypical descriptors for Native people, including 'red willow', 'peace pipe', 'headdress', 'Indian Country', 'Indian chief' and 'Indian squaw'. Search terms were entered independently and, in the case of 'traditional tobacco' and 'sacred tobacco', in combination with 'American Indian'. A full list of search terms is available in online supplementary table 1 . Each tribe has its own language for tobacco ${ }^{11}$ and additional search terms were generated from conversations with diverse tribal members.

Initial searches yielded thousands of documents. Following similar techniques to those identified by other industry document researchers, ${ }^{21}$ only the first 200 search results for each keyword, sorted by relevance, were carefully examined for inclusion. Documents were reviewed and common themes were identified. As part of the iterative process, authors reviewed related and relevant documents (using adjacent Bates numbers, project names and brand names) and verified information on company websites to better contextualise results. Native community member (NV) input guided the interpretation of results ${ }^{23}$ to ensure findings were interpreted with cultural competency and sensitivity.

\section{RESULTS}

A final collection of 76 documents dating from 1935 to 2002 were included for analysis, with the largest number of documents $(n=30)$ dating from the 1990s. Documents came from Philip Morris (PM) (28\%), the Tobacco Institute (17\%), RJR (11\%), Lorillard (11\%), American Tobacco (AT) (11\%), Brown \& Williamson (B\&W) (9\%), Pollay Ads (6\%), British American
Tobacco (5\%) and other collections (2\%). Documents in tobacco company collections did not always reference their own products. For example, documents obtained from PM contained marketing materials for Santa Fe Natural Tobacco Company (SFNTC) and their product, NAS cigarettes.

During the period covered, a general pattern emerged: the earliest documents (1930s-1970s) included the use of Native cultural symbols and imagery. Later documents (1980s-1990s) made explicit connections to the historical context of traditional tobacco use, whereas the most recent documents (1980s-2001) promoted tobacco as natural.

\section{Use of American Indian cultural symbols and imagery}

Forty-nine tobacco industry documents indicated use of American Indian cultural symbols and imagery as a marketing tactic. The earliest documents focused primarily on using Native imagery to sell products. One of the most commonly referenced images before the $1950 \mathrm{~s}$ was the traditional Native headdress. As evidenced in a 1939 ad for Velvet cigarettes, the tagline 'Heap fine flavor' featured an image of a man wearing a traditional headdress (figure 1). ${ }^{24}$ A 1949 Lorillard collection ad for Old Gold cigarettes featured a wooden statue of an Indigenous man in headdress with text "No heap big medicine talk" ${ }^{25}$ Promotional materials for Coupon cigarettes similarly featured a man in full traditional clothing, including a headdress and beaded regalia. ${ }^{26}$ In addition to the use of headdresses in print ads, fictionalised encounters with Native people in traditional clothing and stereotypical language such as "me dumb Injun" ${ }^{27}$ were used for product promotions on radio and in other media. $^{28} 29$

In the 1950s, products continued to use radio ads depicting American Indians, ${ }^{30}$ using narrative describing cultural symbols. Commercials from the 1960s used images of American Indians, including a Kent 'cowboys and Indians'-themed commercial selected for market testing in $1967 .{ }^{31}$ The commercial included 'Indians' approaching a pioneer wagon train as though about to attack, but then showing the cowboys that their 'peace pipe' was broken and they wanted to trade for Kent cigarettes (figure 2).

An overall shift in the tone occurred during the 1980s and early 1990s. Rather than relying on negative American Indian stereotypes, ads instead began to convey a sense of reverence towards Native people and their use of tobacco. For example, a 1980 pitch for 'Indian country cigarettes' from AT stated: "In the more sophisticated atmosphere of the 1980s, there should be an opportunity to use the image of America's original frontiersman: THE INDIAN. The Indian is also the original cultivator of tobacco and the American Tobacco symbol". ${ }^{32}$

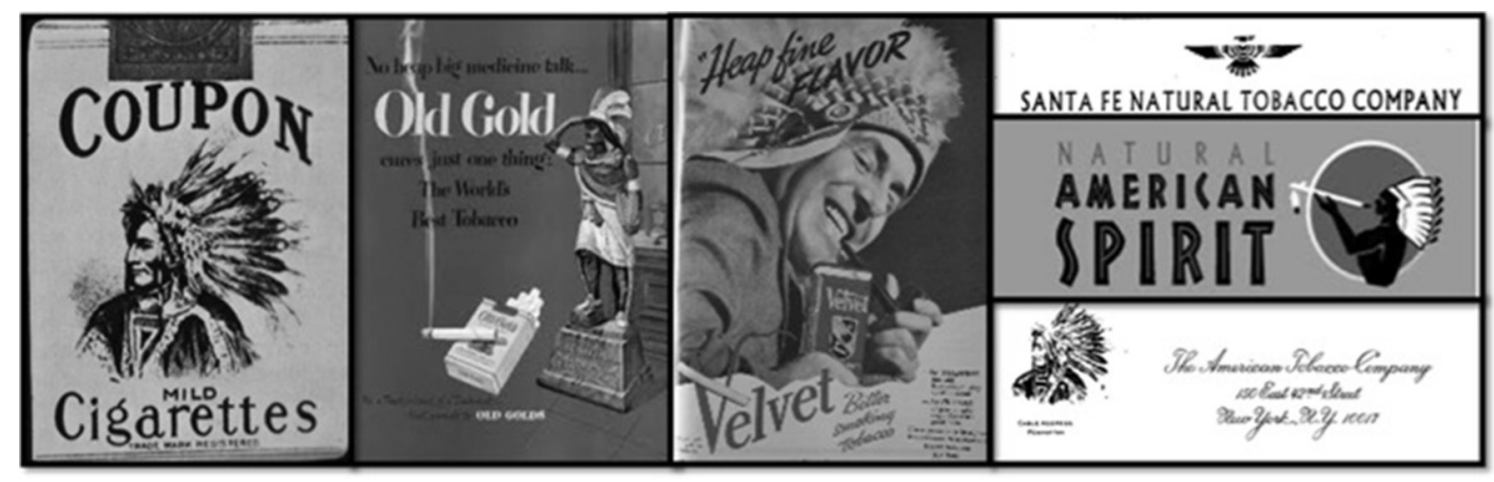

Figure 1 Examples of American Indian images used in tobacco industry marketing. ${ }^{24-263442}$ 


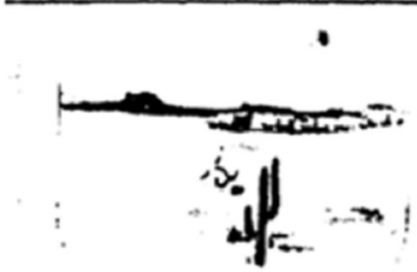

1. (SHENT)

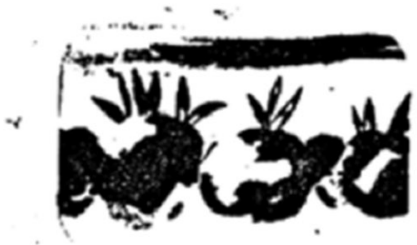

4. What's that? Feation! And cver there--teats

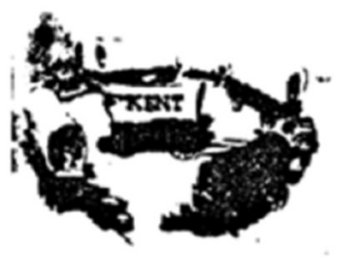

7. The wagon ware all gathered...
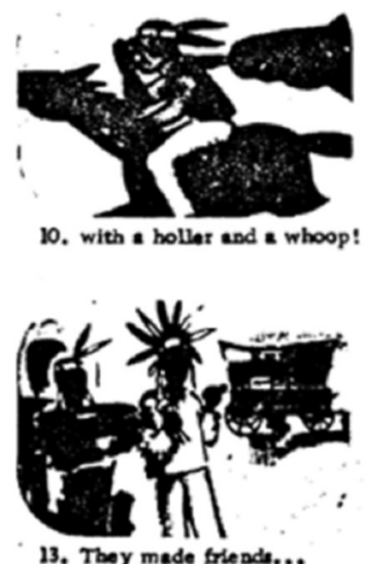

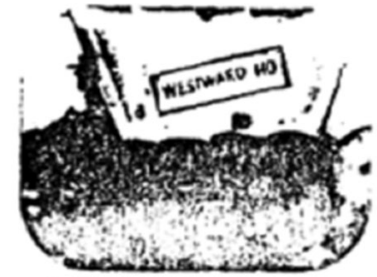

2. NARRATOR: The wasua train moved slowly c ros the preitie wlde...
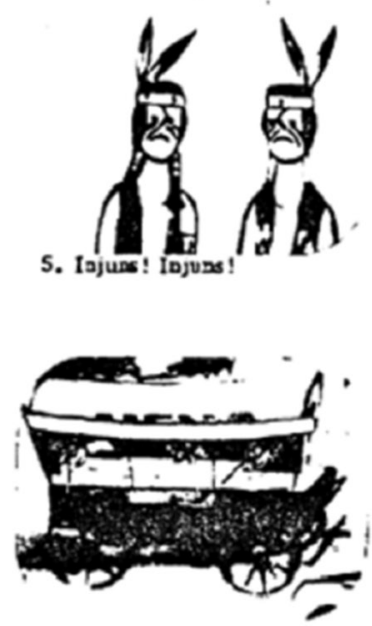

8. for protection in a loop...

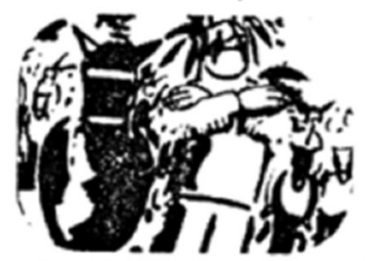

U. Chief Rafocloud dismounced... "We not belligerex:

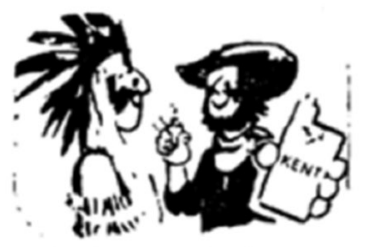

14. SDNGERS: With the taste of Kene.
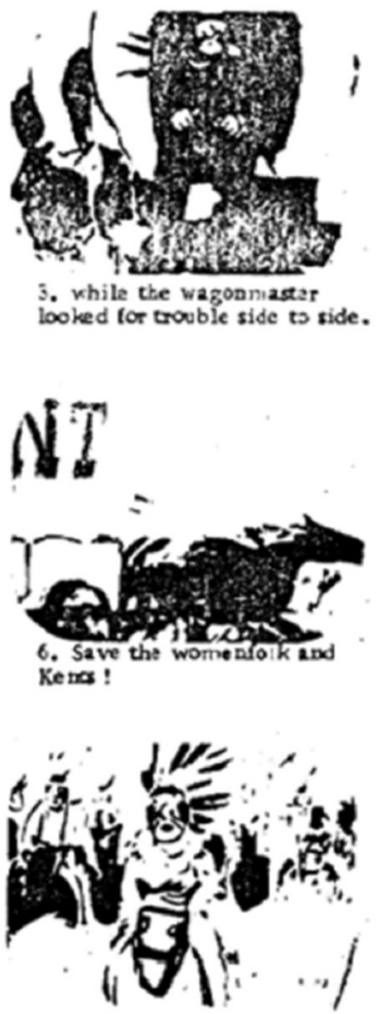

9. The redilins thuncered toward the an...

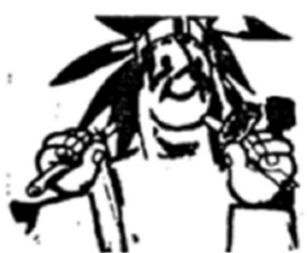

12. Peace -plpe broken. We come to trade for Keats."

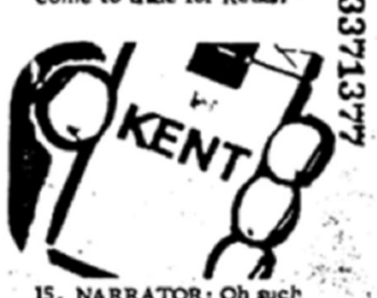

15. NARRAT

Figure 2 Script for Kent cigarettes television commercial 'Wagon Train'. 31

This continued with images portraying American Indians on packages. One 1990 B\&W advertising document described a low-tar cigarette as:

The American Indian (western U.S.) man. A romanticized loner in the American West. Modern-day, but with traditional values and concerns. A noble, historic-but real-figure. More of a symbol than a man with a personality.... Noble, brave, free. The American Indian. ${ }^{33}$

Both $\mathrm{AT}^{34}$ and SFNTC ${ }^{35}$ packaging displayed a man in traditional headdress, and in the case of SFNTC smoking a 'peace pipe' (figure 1). Reverence towards Native culture culminated with the emergence of SFNTC in 1982. Native imagery featured prominently in all NAS marketing materials and on the SFNTC logo and product packaging. In 2000, SFNTC executives dismissed criticisms about the use of AI imagery on packaging while citing the various American Indian funds the company supported: "We'd like to think that we're giving something back to these people in exchange for using this imagery' (figure 3). ${ }^{3637}$

Cultural and historical significance of traditional tobacco

The cultural and historical significance of tobacco to American Indians appeared in a total of 40 documents. Documents in this theme mentioned the use of traditional tobacco as central to the 


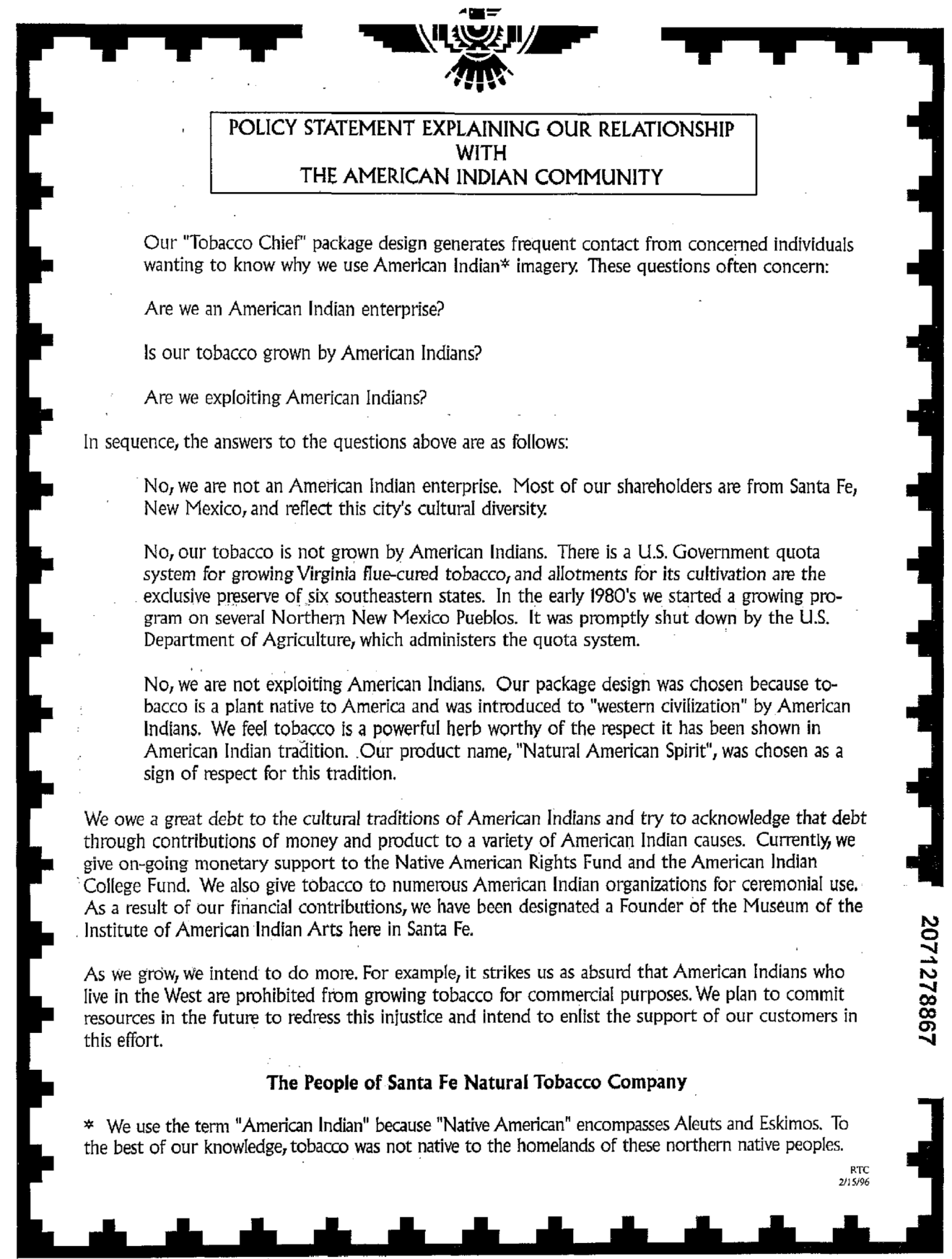

Figure 3 SantaFe Natural Tobacco Company. Answers to your questions about Natural Americancigarettes. Philip Morris Records. February $1996 .^{37}$

lives of many American Indians. Many of these documents used traditional tobacco to justify the use and existence of commercially available tobacco by identifying it as an American tradition pre-dating the tobacco industry by centuries.

A 1951 Lorillard book chronicling the history of the company and its relationship to tobacco referred to the debt owed to the 'red man' for introducing the world to tobacco-stating that it is "their race's gift to grateful humanity". ${ }^{38}$ The document claimed that because American Indians were the first to grow and smoke tobacco, it was only appropriate that Lorillard, as the oldest tobacco company, acknowledged them through images including their own logo as an 'enduring tribute'. ${ }^{38} \mathrm{~A}$ B\&W document from 1998 claimed that the tobacco trade introduced to early colonists by Native peoples was what created the economic foundation for US independence. ${ }^{39}$
An AT document from 1980 pitched the concept of an 'Indian Country' product with the tagline 'the cigarette more American than the cowboy' and the rationale that "The first Americans to smoke were Indians. It's time they took back the credit for inventing the cigarette and got back the country the cowboys took away". ${ }^{32}$ This product was envisioned as a biodegradable ${ }^{40}$ competitor to the iconic 'Marlboro Man'. ${ }^{32}$ Similar use of culture was reinforced in another 1989 Kent ad with a Native elder using a 'peace pipe'. ${ }^{41}$ The ad, written from the elder's perspective, says he smokes because he "happen(s) to enjoy smoking". ${ }^{41}$ Although the ad is for Kent cigarettes, the elder is using a 'peace pipe', with a plea to respect his right to smoke: "I will abide by the rules that you have set. All I ask is that you let me enjoy my Kents, on my turf, in peace". ${ }^{41}$ 
Among other references to the sacred uses of tobacco were NAS sage smudge sticks, ${ }^{42}$ and 'pow-wow blend', which SFNTC said was used in Native ceremonies ${ }^{36}$ and contained amounts of sage, mint, bearberry and red willow ${ }^{42} 43$ (ingredients sometimes used with sacred tobacco for ceremonial purposes). SFNTC also sold and distributed other products associated with American Indian culture, such as Vignette Fact Cards containing stories of tribal leaders ${ }^{44}$ and a 'Book of Elders' collection of interviews with elders across the USA and Canada, ${ }^{45}$ and distributed at least one mailing including a Pueblo tale of sacred tobacco. ${ }^{46}$

\section{Emphasising tobacco as 'natural'}

The final theme identified in the analysis was emphasising tobacco as 'natural' and providing smokers a spiritual or sacred connection to the world, which appeared 22 times. Documents related to SFNTC poignantly illustrate how Native imagery, culture and beliefs were integral to the company's marketing plan. In a 1983 report on competitor activities, RJR shared documents about NAS, the new niche product that used Native imagery and tapped into increasing public interest in all things natural and healthy. ${ }^{47}$ SFNTC Founder Bill Drake was motivated by his beliefs that the pesticides and additives in commercial tobacco were more harmful than tobacco alone. ${ }^{48}{ }^{49} \mathrm{PM}$ research in 1995 found that the message of a pesticide-free and additive-free product resonated with consumers, as the American Indian imagery served as a "reminder of tobacco's original use in its natural state." 35

In a 1995 media profile on SFNTC, CEO Robin Sommers credited his "fascination with American Indian culture" ${ }^{36}$ for inspiring the marketing concept.

The initial thought had to do with American Indian use of tobacco in its natural state, honoring tradition, the respectful nature surrounding the American Indian use of tobacco. Inherent in that concept was tobacco without additives. ${ }^{36}$

SFNTC created an image of their brand NAS as a specialty product too exclusive to be sold in the same venues as other commercial tobacco. ${ }^{50} \mathrm{NAS}$ was sold directly to a small number of retailers, focusing on "health food stores, smoke shops... coffee bars, independent grocers, and gift stores" $" 50$ to further reinforce the 'natural' aspect of tobacco and join the broader health-conscious movement of the 1980s and 1990s ${ }^{50}$ Part of this image was carefully cultivated by marketing products as 'additive-free' and using only certified organic tobacco. ${ }^{36}$ In 1996, SFNTC management recognised that consumers were becoming more interested in what they were putting into their bodies and started showing preference for organic and chemical-free options. SFNTC saw an opportunity to fill that niche within the cigarette world. ${ }^{50}$

Research conducted by industry competitors found that the use of American Indian imagery by SFNTC served to "bond people with America's origins". ${ }^{35}$ PM found that the logos and graphics on NAS packaging led consumers to believe that smoking cigarettes was a normal human activity and that they were supporting a worthy Native cause (assuming that the brand was under American Indian ownership). ${ }^{35}$ Focus groups held by consultants for $\mathrm{B} \& \mathrm{~W}$ found that the use of American Indian imagery contributed to consumers' perceptions that SFNTC was a small company creating a healthier, more natural product. ${ }^{51}$ PM concluded that the images used by SFNTC contributed significantly to smokers' emotional connection and loyalty with these products. ${ }^{35}$

In one 1994 promotional document, ${ }^{42}$ SFNTC referred to the use of 'natural' tobacco as being closer to the way it was intended to be used — as part of American Indian traditions—and completely separate from nicotine addiction. The connection between traditional tobacco and the 'natural' marketing technique seemed to resonate with one customer in particular, who was featured in a SFNTC promotional document and said (of her husband):

... his desire to smoke is as old and natural as humanity itself. It is his spirit saying, 'I need ... to step aside and get in touch with the peace within.' ... They have put the 'Spirit' back into his smoking—as it should be. ${ }^{42}$

SFNTC paired Native imagery with descriptors such as 'natural' and 'organic', but also included statements that additive-free products were not safer than other forms of commercial tobacco. ${ }^{52}$ Despite this, SFNTC included testimonials from customers who reported they were smoking a less harmful product because it was 'natural'. ${ }^{42}$

\section{DISCUSSION}

To our knowledge, this is the first systematic examination of tobacco industry documents focused on how marketing tactics incorporated American Indian culture and traditional tobacco. Findings demonstrate that the tobacco industry used American Indian imagery and symbols in its branding, portrayed harmful stereotypes in its advertising, and exploited relationships with sacred tobacco, thereby misappropriating tradition and culture. The tobacco industry co-opted cultural traditions that are integral to the lives of many American Indians, similar to tactics that have been used in other racial/ethnic minority communities, ${ }^{15}$ but in this instance, directed at the very core of American Indian values and belief systems. ${ }^{7}$

Our results suggest industry marketing incorporated Native imagery and cultural objects for decades. Earliest depictions commodified cultural symbols such as headdresses and peace pipes. Descriptors such as "noble, brave, and free", ${ }^{33}$ as well as offensive portrayals of colloquial language such as Lorillard's "no heap big medicine talk"25 (figure 1) may reinforce public misconceptions of Native people while ignoring the rich history that traditions and words have for many Native cultures. ${ }^{53}$

A fascination with the romanticised ideal of Native culture prompted the marketing concept for NAS. However, these types of representations dehumanise diverse peoples and cultures, contributing to ignorance among non-Natives, and could result in Native people internalising negative perceptions of their culture. ${ }^{154}$ Misappropriation and misuse of American Indian names, signs and symbols are not limited to tobacco products ${ }^{55}$; previous research has identified commodification of American Indian images on products like Crazy Horse Malt Liquor ${ }^{56}$ and Big Chief Sugar, ${ }^{54}$ as well as sports teams' mascots, which have prompted much debate in recent years. ${ }^{57}$ Given historical trauma and continued disenfranchisement of Native people, there is a need for the immediate end to discriminatory and degrading use of Native imagery that takes a toll on health and undermines the intellectual property rights of Indigenous communities. ${ }^{55} 57$

In many industry documents, there was acknowledgement of tobacco's connection to Native culture. The tobacco industry used this knowledge to validate the claim that Native tobacco practices were the foundation for the creation of the tobacco industry. In doing so, the tobacco industry also capitalised on the connection between Native peoples and tobacco in their use of Native imagery as symbols and logos for marketing purposes.

We noted a transition from stereotypical and often negative representations of Native people in the mid-1900s to later documents portraying a reverence for Native heritage and spiritual 
beliefs as a way to tie commercial tobacco back to its historical origins, and finally marketing commercial tobacco as a natural product. It is notable that SFNTC, more than any other company, explicitly referenced the distinction between sacred and commercial use and tobacco's traditional role in American Indian communities. Native culture was featured in packaging and advertising, and also woven into the company's positioning as a natural, additive-free product.

SFNTC sold products such as smudge sticks and pow-wow blend tobacco and prominently featuring ceremonial regalia and pipes in branding. These depictions do not consider the cultural significance of these sacred objects, but are solely focused on the sale of a commodity. ${ }^{10}$ However, for Native communities, there are strict protocols for wearing a traditional headdress or being gifted a pipe. There are also specific instructions around growing and harvesting traditional tobacco, which can only be done by certain community members under protocols. These misrepresentations of significant cultural practices outside their traditional context illustrate commodification of culture to market commercial tobacco. Future studies should explore how Native imagery, especially when paired with descriptors such as 'natural' and 'additive-free', contributes to public perceptions about the safety of these products. Research is also needed to understand the impact of cultural misrepresentations on high rates of commercial tobacco use among American Indians. Additionally, future research examining how the tobacco industry may have specifically targeted American Indians as well as how these tactics compare with those used towards other consumer groups is needed.

Our findings have several implications for advocacy and practice. This study reinforces the need to counter tobacco industry tactics directed at exploiting Native culture as part of a comprehensive framework to reduce the burden of commercial tobacco use. The Stop the Sale of our Image: Don't Buy the Lie campaign (figure 4) from California offers an example of a community-based campaign to counter pro-tobacco influences. ${ }^{58}$ In Minnesota, the Keep Tobacco Sacred campaign also emphasises the original intention of tobacco among Native people and honouring traditional tobacco as a sacred gift (figure 5). ${ }^{59}$ Community-based strategies, framed within an assets-based context, can promote health and healing in Native communities and contribute to a broader movement to restore traditional tobacco and reclaim Native culture. ${ }^{7}$

Our study has several limitations. Because some of the industry documents are restricted (due to confidential information) and of the sheer volume of documents, we were unable to determine whether all documents relevant to our research question were

\section{STOP IUTE SALE OF OUR TMAAB}

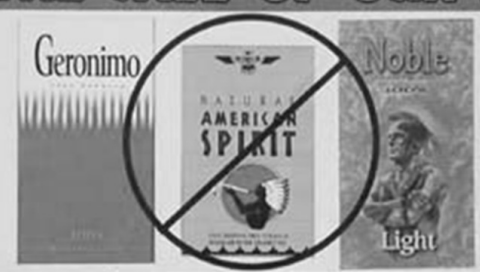

DONTT BU] TUI 니

Figure 4 California example of counter-marketing strategy against tobacco industry misappropriation of American Indian tradition. ${ }^{58}$

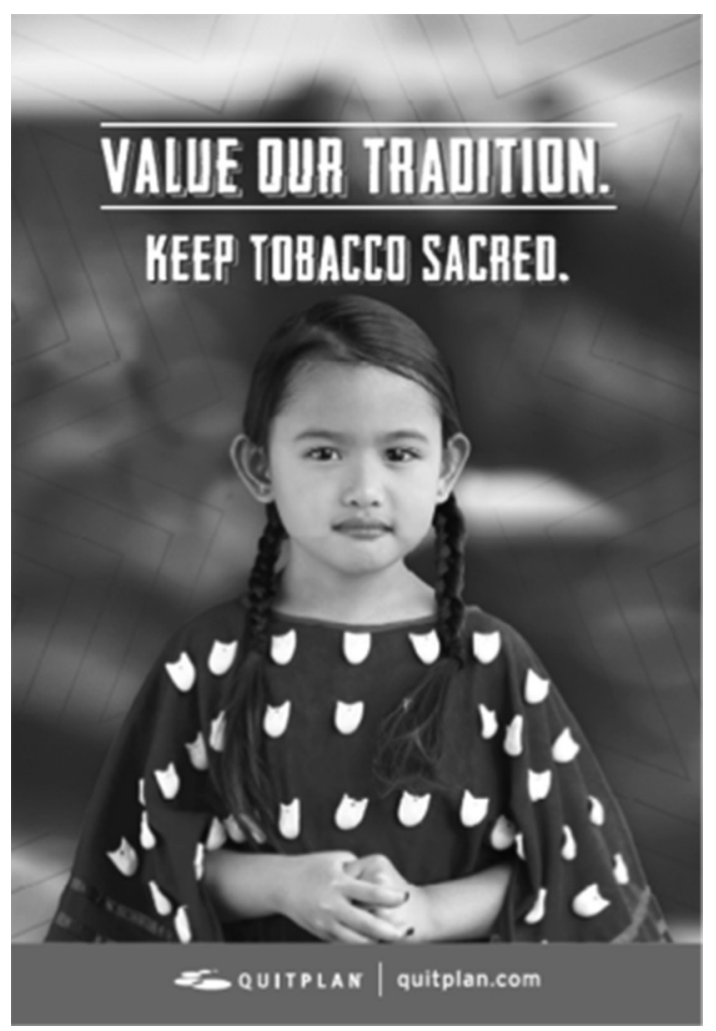

Figure 5 Minnesota example of counter-marketing strategy against tobacco industry misappropriation of American Indian tradition. ${ }^{59}$

included. For example, we were unable to find any internal documents from SFNTC prior to 2002 (when SFNTC was acquired by RJR) because they were a small, private company and not subject to the disclosure requirements of the Master Settlement Agreement. ${ }^{60}$ Given the scope of our research question, we excluded documents regarding the complex issues of sovereignty and tribally owned tobacco entities. These issues warrant further examination and need to be respectfully considered in light of the complex political and economic realities facing American Indian tribes. $^{761}$

The tobacco industry utilised American Indian history, culture and images for marketing and commodified a culture and people deeply connected to traditional tobacco, but also disproportionately impacted by the harms of commercial tobacco use. ${ }^{14}$ Our findings underscore the need to counter tobacco industry influence as part of a comprehensive approach to addressing commercial tobacco use, by monitoring tactics that misrepresent culture and co-opt tradition. Such efforts, embedded within a culturally sensitive, community-driven approach, may help reduce the burden of commercial tobacco use.

\section{What this paper adds}

- The tobacco industry has used cultural attributes to market its tobacco products.

- No previous literature has examined the extent to which the tobacco industry incorporated American Indian culture and traditional tobacco in their marketing tactics.

- Documents revealed that the tobacco industry used Native imagery in their advertising, commodified sacred tobacco and other cultural objects, and misrepresented cultural practices to sell commercial tobacco. 
Acknowledgements The authors would like to thank Raymond G Boyle, Jaime $\mathrm{L}$ Martinez, Barbara A Schillo, Claradina Soto and Valerie B Yerger for their thoughtful feedback on early versions of this manuscript. We also wish to acknowledge Dominick Knutson, Kristy LeBlanc, Laura Keys and Maira Rosas Lee for their contributions to the preliminary conceptualisation of this project.

Contributors JD and NV led the conceptualisation of this manuscript. JD, EO and NV conducted data collection and EO led the data analysis. All authors contributed substantively to writing, revising and final review.

Competing interests None declared.

Provenance and peer review Not commissioned; externally peer reviewed.

Data sharing statement All tobacco industry documents are available electronically via the Truth Tobacco Documents Library.

Open access This is an open access article distributed in accordance with the Creative Commons Attribution Non Commercial (CC BY-NC 4.0) license, which permits others to distribute, remix, adapt, build upon this work non-commercially, and license their derivative works on different terms, provided the original work is properly cited and the use is non-commercial. See: http://creativecommons.org/ licenses/by-nc/4.0/

(c) Article author(s) (or their employer(s) unless otherwise stated in the text of the article) 2018. All rights reserved. No commercial use is permitted unless otherwise expressly granted.

\section{REFERENCES}

1 Merskin D. Winnebagos, Cherokees, Apaches, and Dakotas: the persistence of stereotyping of American Indians in American advertising brands. How J C 2001;12:159-69.

2 Hodge FS, Geishirt Cantrell BA, Struthers R, et al. American Indian internet cigarette sales: another avenue for selling tobacco products. Am J Public Health 2004;94:260-1.

3 Pearson JL, Richardson A, Feirman SP, et al. American spirit pack descriptors and perceptions of harm: a crowdsourced comparison of modified packs. Nicotine Tob Res 2016;18:1749-56.

4 Moran MB, Pierce JP, Weiger C, et al. Use of imagery and text that could convey reduced harm in American Spirit advertisements. Tob Control 2017;26:e68-70.

5 Unger JB, Soto C, Baezconde-Garbanati L. Perceptions of ceremonial and nonceremonial uses of tobacco by American-Indian adolescents in California. $J$ Adolesc Health 2006:38:443.e9-16.

6 Blackfeet Nation. Blackfeet tobacco free act. 2005 http://indigenouspeoplestf.org/ toolkit/policy/BLACKFEETTRIBALORDINANCE.29092915.pdf (accessed 28 Jun 2017).

7 Boudreau G, Hernandez C, Hoffer D, et al. Why the world will never be tobacco-free: reframing "Tobacco Control" into a traditional tobacco movement. Am J Public Health 2016;106:1188-95.

8 Struthers R, Hodge FS. Sacred tobacco use in Ojibwe communities. $J$ Holist Nurs 2004:22:209-25.

9 Hodge FS, Struthers R. Persistent smoking among Northern Plains Indians: Ienient attitudes, low harm value, and partiality toward cigarette smoking. J Cult Divers 2006;13:181-5.

10 BlueEye L. Use of Native American imagery to sell tobacco. J Okla State Med Assoc 2004;97:195-6.

11 Forster J, Rhodes K, Poupart J, et al. Patterns of tobacco use in a sample of American Indians in Minneapolis-St. Paul. Nicotine \& Tobacco Research 2007;9:29-37.

12 An act to provide for the allotment of lands in severalty to indians on the various reservations (General Allotment Act or Dawes Act). In: Congress US ed. Statutes at Large 24, 388-91, NADP Document A1887, 1887

13 American Indian Religious Freedom Act. In: 95th Congress, ed. Vol 92 STAT. 469, 1987. Public Law No. 95-341

14 Jamal A, King BA, Neff LJ, et al. Current cigarette smoking among adults—United States, 2005-2015. MMWR Morb Mortal Wkly Rep 2016;65:1205-11.

15 U.S. Department of Health and Human Services. Tobacco Use Among U.S. Raciall Ethnic Minority Groups-African Americans, American Indians and Alaska Natives, Asian Americans and Pacific Islanders, and Hispanics: A Report of the Surgeon General. Atlanta, GA, 1998.

16 Iglesias-Rios L, Parascandola M. A historical review of R.J. Reynolds' strategies for marketing tobacco to Hispanics in the United States. Am J Public Health 2013;103:e15-27.

17 Yerger VB, Przewoznik J, Malone RE. Racialized geography, corporate activity, and health disparities: tobacco industry targeting of inner cities. J Health Care Poor Underserved 2007:18(4 Suppl):10-38.

18 National Cancer Institute. The Role of the Media in Promoting and Reducing Tobacco Use. Vol Tobacco Control Monograph No. 19. Bethesda, MD: U.S: Department of Health and Human Services, National Institutes of Health, National Cancer Institute, 2008.

19 Mukherjea A. Tobacco industry co-optation of culture? Converging culturally specific and mainstream tobacco products in India. Tob Control 2012;21:63-4.
20 Unger JB, Cruz T, Shakib S, et al. Exploring the cultural context of tobacco use: a transdisciplinary framework. Nicotine Tob Res 2003:5(Suppl 1):101-7.

21 Anderson SJ, McCandless PM, Klausner K, et al. Tobacco documents research methodology. Tob Control 2011;20(Suppl 2):ii8-11.

22 Malone RE, Balbach ED. Tobacco industry documents: treasure trove or quagmire? Tob Control 2000:9:334-8.

23 Israel BA, Schulz AJ, Parker EA, et al. Review of community-based research: assessing partnership approaches to improve public health. Annu Rev Public Health 1998;19:173-202

24 Liggett. Heap Fine Flavor. Richard W. Pollay Cigarette Ads Collection, 1939. https:// www.industrydocumentslibrary.ucsf.edu/tobacco/docs/\#id=pgkg0026

25 Lorillard. No Heap Big Medicine Talk. Richard W. Pollay Cigarette Ads Collection, 1949. https://www.industrydocumentslibrary.ucsf.edu/tobacco/docs/\#id=sgwg0026

26 Anon. Coupon Mild Cigarettes. Richard W. Pollay Cigarette Ads Collection. https:// www.industrydocumentslibrary.ucsf.edu/docs/\#id=tzvd0050

27 IKJ National Broadcasting. Uncle Ezra's Radio Station. \#51. RJ Reynolds Records, 1941. https://www.industrydocumentslibrary.ucsf.edu/docs/\#id=grdc0079

28 Anon. Scripts. American Tobacco Records, 1946. https://www.industrydocument slibrary.ucsf.edu/docs/\#id=fqbx0017

29 Etsy W. The Abbott and Costello Program for Camel Cigarettes. NBC — Studio "A". Program No. 9. Marketing to Minorities, Military, and Gays MSA Collection, 1946. https://www.industrydocumentslibrary.ucsf.edu/docs/\#id=fmdb0048

30 Etsy W. Radio. RJ Reynolds Records, 1952. https://www.industrydocumentslibrary.ucsf. edu/docs/\#id=ptxh0091

31 Burke Marketing Research. Kent Cigarettes Television Commercial On-Air Study "Wagon Train" (60 Seconds). Lorillard Records, 1967. https://www.industrydocument slibrary.ucsf.edu/docs/\#id=yfbg0129

32 Anon. American Tobacco Company, New Product Exploratory. American Tobacco Records, 1980. https://www.industrydocumentslibrary.ucsf.edu/docs/\#id=tpyf0144

33 Anon. American Indian. Brown \& Williamson Records, 1990. https://www.industry documentslibrary.ucsf.edu/docs/\#id=xtxk0102

34 Anon. Circular Book, November 2, 1965 to December 24, 1965. American Tobacco Records:1965. https://www.industrydocumentslibrary.ucsf.edu/docs/\#id=fnnn0174

35 Anon. Natural American Spirit [Brand and Product Overview]. Philip Morris Records, 1995. hhttps://www.industrydocumentslibrary.ucsf.edu/docs/\#id=|pbn0154

36 Crellin R. Organic Tobacco. British American Tobacco Records, 2000. https://www.indu strydocumentslibrary.ucsf.edu/docs/\#id=thnm0197

37 Santa Fe Natural Tobacco Company. Natural American Spirit Tobacco Products. American Tobacco Records, 1993. https://www.industrydocumentslibrary.ucsf.edu/ docs/\#id=njkw0020

38 Downey FL. Lorillard and Tobacco. Lorillard Records, 1951. https://www.industrydocu mentslibrary.ucsf.edu/docs/\#id=mffp0015

39 Brown and Williamson. Brown and Williamson, Main Street USA; N329. Philip Morris Records, 1998. https://www.industrydocumentslibrary.ucsf.edu/docs/\#id=ghxx0085

40 Hayes T. No Title [AT new product memo]. American Tobacco Records, 1980. https:// www.industrydocumentslibrary.ucsf.edu/docs/\#id=smpp0142

41 Anon. Let's Smoke the Peace Pipe. Keep it Light. Make it Kent. Lorillard Records, 1989 https://www.industrydocumentslibrary.ucsf.edu/docs/\#id=zqph0129

42 Anon. Santa Fe Natural Tobacco Company [Mailing Form with Customer Letters]. Philip Morris Records, 1994. http://industrydocuments.library.ucsf.edu/tobacco/docs/ lhbg0025

43 Bordeaux N. American Spirit Pouch Blends. Philip Morris Records, 1995. https://www. industrydocumentslibrary.ucsf.edu/docs/\#id=tklw0028

44 Anon. RJR Websites, Santa Fe Natural Tobacco Company. RJ Reynolds Records, 2001. https://www.industrydocumentslibrary.ucsf.edu/docs/\#id=jqgk0023

45 Santa Fe Natural Tobacco Company [Direct Mailing with Free Sample and Order Form]. Philip Morris Records, 1995. https://www.industrydocumentslibrary.ucsf.edu/ docs/\#id=kpyv0044

46 Santa Fe Natural Tobacco Company. Natural American Spirit Tobacco Products. American Tobacco Records, 1993. https://www. industrydocumentslibrary. ucsf. edu/ doc s/\# id= njkw0020

47 Miller TE. Marketing Intelligence Report. Competitive Activities. RJ Reynolds Records, 1983. https://www.industrydocumentslibrary.ucsf.edu/docs/\#id=Ilww0098

48 Drake W. Warning —Diatribe Ahead New Strategies for Cigarette Victims. Philip Morris Records, 1997. https://www.industrydocumentslibrary.ucsf.edu/docs/\#id=zzwl0067

49 Drake W. The European Experience with Native American Tobacco. Philip Morris Records, 1997. https://www.industrydocumentslibrary.ucsf.edu/docs/\#id=pzwl006

50 Kaplan A. Category Management: Cigarettes New Ways to Carve a Niche. Lorillard Records, 1996. https://www.industrydocumentslibrary.ucsf.edu/docs/\#id= mzwj0049

51 Goldfarb Consultants. Perceptions of American Spirit, Red Kamel \& Moonlight Tobacco. Brown \& Williamson Records, 1997. https://www.industrydocumentslibrary. ucsf.edu/docs/\#id=shmm0078

52 Natural American Spirit. Introducing Natural American Spirit Account Representatives. Brown \& Williamson Records, 1990. https://www.industrydocumentslibrary.ucsf.edu/ docs/\#id=phmm0078

53 Mclvor 0, Napoleon A, Dickie KM. Language and culture as protective factors for at-risk communities. Int J Indig Health 2009;5:6-25. 
54 Merskin D. How many more Indians? An argument for a representational ethics of Native Americans. J Commun Inq 2014;38:184-203.

55 Johnsson D. The branding of traditional cultural expressions: to whose benefit? Indigenous Peoples' Innovation: Intellectual Property Pathways to Development. Canberra ACT: Australian National University E-Press, 2012.

56 Moore DJ, Williams JD, Qualls WJ. Target marketing of tobacco and alcohol-related products to ethnic minority groups in the United States. Ethn Dis 1996;6:83-98.

57 National Congress of American Indians. Ending the Legacy of Racism in Sports \& The Era of Harmful "Indian" Sports Mascots. 2013 http://www.ncai.org/attachments/ PolicyPaper_mijApMoUWDbjgFtjAYZQWIqLdrwZvsYfakBwTHpMATcOroYolpN_NCAI_ Harmful_Mascots_Report_Ending_the_Legacy_of_Racism_10_2013.pdf
58 Billboards decry use of Indian images. NCJ 2003 https://www.northcoastjournal.com/ 032703/news0327.html\#anchor624790 (accessed 28 Jun 2017).

59 ClearWay Minnesota. Keep tobacco sacred. http://clearwaymn.org/keeptobaccosacred/ (accessed 28 Jun 2017)

60 Tobacco Control Legal Consortium. The master settlement agreement: an overview. 2015 http://www. publichealthlawcenter.org/sites/default/files/resources/tclc-fs-msaoverview-2015.pdf (accessed 28 Jun 2017).

61 Chief C, Sabo S, Clark H, et al. Breathing clean air is Są'áh Naagháí Bik'eh Hózhóó (SNBH): a culturally centred approach to understanding commercial smoke-free policy among the Diné (Navajo People). Tob Control 2016;25(Suppl 1):i19-25. 